\title{
Conceptualizing Collective Bargaining under the Charter: The Enduring Problem of Substantive Equality
}

Judy Fudge

Osgoode Hall Law School of York University

Follow this and additional works at: http://digitalcommons.osgoode.yorku.ca/sclr

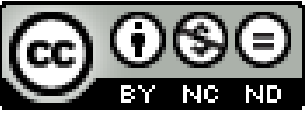

This work is licensed under a Creative Commons Attribution-Noncommercial-No Derivative Works 4.0 License.

\section{Citation Information}

Fudge, Judy. "Conceptualizing Collective Bargaining under the Charter: The Enduring Problem of Substantive Equality." The Supreme Court Law Review: Osgoode's Annual Constitutional Cases Conference 42. (2008).

http://digitalcommons.osgoode.yorku.ca/sclr/vol42/iss1/9 


\title{
Conceptualizing Collective Bargaining under the Charter: The Enduring Problem of Substantive Equality
}

\author{
Judy Fudge*
}

Collective bargaining also enhances the Charter value of equality. One of the fundamental achievements of collective bargaining is to palliate the historical inequality between employers and employees. ${ }^{1}$

\section{INTRODUCTION}

The Supreme Court of Canada's decision in Health Services and Support-Facilities Subsector Bargaining Assn. v. British Columbia ${ }^{2}$ was both remarkable and unexpected; not only did the Court expressly overrule 20 years of jurisprudence interpreting the freedom of association as excluding collective bargaining, ${ }^{3}$ it did so in a case that

\footnotetext{
Professor and Lansdowne Chair in Law, University of Victoria. I would like to thank the Social Sciences and Humanities Research Council for funding the research upon which this article is based.

Health Services and Support-Facilities Subsector Bargaining Assn. v. British Columbia, [2007] S.C.J. No. 27, [2007] 2 S.C.R. 391, at para. 84 [hereinafter "B.C. Health Services"].

Id.

3 In the Labour Trilogy, which refers to three concurrently released appeals (Reference re Public Service Employee Relations Act (Alta.), [1987] S.C.J. No. 10, [1987] 1 S.C.R. 313 (S.C.C.) [hereinafter "Alberta Reference"], Public Service Alliance of Canada v. Canada, [1987] S.C.J. No. 9, [1987] 1 S.C.R. 424 (S.C.C.), and RWDSU v. Saskatchewan, [1987] S.C.J. No. 8, [1987] 1 S.C.R. 460 (S.C.C.)), a plurality of the Court held that s. 2(d) of the Canadian Charter of Rights and Freedoms, Part I of the Constitution Act, 1982, being Schedule B to the Canada Act, 1982 (U.K.) 1982, c. 11 [hereinafter "Charter"] did not include collective bargaining. The main reasons were delivered in the Alberta Reference, a case involving compulsory arbitration to resolve impasses in collective bargaining and a prohibition on strikes. Of the six justices participating in the case, three held that collective bargaining was not protected by s. 2(d); four held that strike activity was not protected. The next case to deal with the issue was Professional Institute of the Public Service of Canada v. Northwest Territories (Commissioner), [1990] S.C.J. No. 75, [1990] 2 S.C.R. 367 (S.C.C.) [hereinafter "PIPSC"], in which the Government of the Northwest Territories refused to enact legislation required in order for the PIPSC (union) to bargain collectively on behalf of nurses.
} 
dealt with collective bargaining in the health-care sector, a politically charged area in which the Court's recent forays had been extremely controversial. ${ }^{4}$ The case has garnered a great deal of attention from constitutional pundits who predict dire consequences for both the health care system and the "Canadian constitutional fabric", labour lawyers and academics who study labour law and workers' rights. ${ }^{5}$ Even among labour law academics sympathetic to providing constitutional protection for workers' rights, the Court's reasoning has attracted a fair measure of criticism. ${ }^{6}$ Moreover, the case has generated a great deal of speculation regarding the scope of the constitutional protection of freedom of association. In some (but not other) instances, provincial governments have responded to the Court's ruling by extending labour legislation to include previously excluded groups of government and broader public sector employees. ${ }^{7}$ It has also triggered a spurt of litigation that

A majority of four held that collective bargaining was not protected by s. 2(d). In 2001 in Dunmore v. Ontario (Attorney General), [2001] S.C.J. No. 87, [2001] 3 S.C.R 1016 (S.C.C.) [hereinafter "Dunmore"], the Court affirmed its position that freedom of association protected in the Charter did not include collective bargaining.

4 The Supreme Court has evinced great concern for the fiscal health of Canada's healthcare sector, which is essentially a single (government) payer system. In Chaoulli v. Quebec (Attorney General), [2005] S.C.J. No. 33, [2005] 1 S.C.R. 791 (S.C.C.), the Court opened the door to the privatization of health care by permitting private health insurance in limited circumstances in Quebec. In Newfoundland (Treasury Board) v. Newfoundland Assn. of Public Employees (NAPE), [2004] S.C.J. No. 61, [2004] 3 S.C.R. 381 (S.C.C.) [hereinafter "Newfoundland v. NAPE"], the Court accepted the Newfoundland government's fiscal concerns as an acceptable justification to cancel an agreed upon pay equity payment and thereby to violate women's equality rights.

Pamela Fayerman, "Court ruling 'bolsters' private health care; Governments will now find it harder to restructure system, legal expert says" Vancouver Sun, June 20, 2007, at B1, reported that Patrick Monahan told a B.C. Government Health symposium that one of the unintended consequences of the B.C. Health Services case is that it will result in a market for supplementary private health insurance to pay for care in the private sector. According to Robert Charney, in "The Contract Clause Comes to Canada: The British Columbia B.C. Health Services Case and the Sanctity of Collective Agreements" (unpublished paper), the decision has the potential to result in "a significant interference with government regulation, and to impose laissez-faire economic principles on the Canadian constitutional fabric". (Quoted in Jamie Cameron, "Due Process, Collective Bargaining and Section 2(d) of the Charter: A Comment on B.C. Health Services" (2008) 42 S.C.L.R. (2d) 131, at 142, fn. 45.)

6 See Eric Tucker, "The Constitutional Right to Bargain Collectively: The Ironies of Labour History in the Supreme Court of Canada" (2008) 61 Labour/Le Travail 151 [hereinafter "Tucker"], for a criticism of the Supreme Court of Canada's use of history, and Brian Langille, "Can We Rely on the ILO? (Don't Ask the Supreme Court of Canada)" (2008) 13 C.L.E.L.J. 363, who criticizes the decision for misunderstanding international labour law.

About 2,000 seasonal and casual workers in Nova Scotia will receive collective bargaining rights under proposed legislation, "Seasonal workers to gain bargaining rights, benefit" The Globe and Mail, December 1, 2007, at A13. The Chair of the Labour Relations Board, Kevin Whitaker, was appointed by the Ontario government to study and to report on whether collective bargaining rights should be extended to part-time college teachers. His February 2008 report, A 
challenges a raft of restrictive labour legislation as unconstitutional. ${ }^{8} \mathrm{~A}$ recent decision by the Quebec Superior Court, ${ }^{9}$ which (like the B.C. case) involved legislation that radically restructured labour relations and collective bargaining in the health care sector, suggests that the B.C. Health Services case will be stirring up a lot of constitutional rightsrelated dust unless the Supreme Court of Canada steps in to dampen the lower courts' enthusiasm for a robust interpretation of freedom of association in the labour context.

In an earlier article, I addressed two broad questions: what gave rise to the decision and what does it portend for the role of the courts in labour relations in Canada. ${ }^{10}$ This article builds upon the earlier one;

Review of the College Collective Bargaining Act: Report of the Advisor to the Minister of Training, Colleges and Universities, recommended that collective bargaining rights be extended to part-time college teachers (at 52), noting that their exclusion from collective bargaining legislation was "most likely" a violation of the Charter (at 35). The Ontario government has introduced legislation (Bill 90, Colleges Collective Bargaining Act, 2008, 49th Sess., Second Reading, June 12, 2008) extending collective bargaining rights to part-time college teachers (although this legislation would repeal provisions that currently prohibit members of the bargaining unit that is on strike or lockout from working during lawful collective action). However, no similar announcement has been made with respect to extending labour legislation to agricultural workers, who since 1996 have been going to court in order to challenge their exclusion from collective bargaining legislation in Ontario. See Dunmore, supra, note 3, and Fraser v. Ontario (Attorney General), [2006] O.J. No. 45, 79 O.R. (3d) 219 (Ont. S.C.J.), and related action [2008] O.J. No. 1219, 2008 ONCA 222 (Ont. C.A.).

8 British Columbia teachers' unions are challenging legislation that restructured collective bargaining in the education sector. Members of the RCMP are challenging their exclusion from collective bargaining legislation in the federal sector. Four construction unions in Alberta are challenging provisions in the Alberta Labour Relations Code, R.S.A. 2000, c. L-1 that prohibit unions and employers from resorting to strike and lockouts and substituting instead binding arbitration to resolve disputes relating to the negotiation of collective agreements if 75 per cent of the group of trade unions and registered employers' organizations in the construction sector have entered into collective agreements. Two national unions representing professional employees in the federal public sector have launched legal challenges to provisions in the Public Service Labour Relations Act, S.C. 2003, c. 22, s. 2 that restricts their ability to negotiate staff, job classifications and pension benefits.

Confédération des syndicats nationaux v. Québec (Procureur général), [2007] J.Q. no 13421, 2007 QCCS 5513 (Que. C.S.) (November 30, 2007, Judge Claudine Roy). For an English summary of this decision see Lancaster House Headlines, January 10, 2008. This decision contrasts markedly with the decision by Farley J. in Fraser v. Ontario (Attorney General), supra, note 7. Justice Farley took a wait-and-see approach to a challenge brought by the United Food and Commercial Workers' Union that the Agricultural Employees Protection Act, 2002, S.O. 2002, c. 16, which was introduced by the government in response to the Supreme Court of Canada's decision in Dunmore, supra, note 3, did not pass constitutional muster.

10 "The Supreme Court of Canada and the Right to Bargain Collectively in Canada and Beyond" (2008) 37(1) Indus. L.J. 25-48. In so doing, I examined the Supreme Court's reasoning in order to assess what it means for future constitutional challenges to limitations on collective bargaining. Using the Supreme Court's reliance on international labour law in its interpretation of s. 2(d) as my point of departure, I focused on two issues (whether the constitutional protection for freedom of association includes either the right to strike or promotes forms of minority unionism that fall outside the majority and exclusive unionism associated with the Wagner Act and its 
however, it is neither descriptive nor predictive. Instead my goal is threefold. First, I will attempt to understand how the Supreme Court conceptualizes the constitutionally protected right to bargain collectively. The reason why I am concerned with this conceptual question is because I am troubled by the Court's brief, and dismissive, treatment of the argument that the impugned legislation violated the affected health care workers' equality rights. My suspicion is that the Court has adopted a purely formal or procedural approach to collective bargaining that cannot address the problem of substantive inequality. Although this approach may promote democratic deliberation by requiring governments to consult with the unions representing government employees who will be adversely effected by legislation that interferes with collective agreements, my concern is that it is disconnected from a broader, deeper and more secure normative base upon which to ground labour rights. Second, I will attempt to show that the Supreme Court's dismissive treatment of the equality argument is not only inconsistent with its decision in Newfoundland (Treasury Board) v. Newfoundland Assn. of Public Employees (NAPE), ${ }^{11}$ it both reflects and promotes an idea of equality that is directed at fighting stereotypes to the exclusion of fostering substantive equality. Third, I want to suggest that constitutional litigation in the labour context supports and reinforces partisan politics by promoting a form of aggressive adversarialism that is antithetical to a principled approach to developing labour policy for an economy for which the prevailing form of industrial pluralism no longer fits.

\section{ConcePtuAlizing Collective BARGAining}

In the B.C. Health Services case, the Supreme Court of Canada held that "the s. 2(d) guarantee of freedom of association [in the Canadian Charter of Rights and Freedoms] protects the capacity of members of labour unions to engage in collective bargaining on workplace issues." 12 Taking Dunmore v. Ontario (Attorney General) as their point of departure, McLachlin C.J.C. and LeBel J., the authors of the judgment

Canadian counterparts) in order to explore the relationship between domestic constitutional law in Canada and international norms in the labour context.

11 Supra, note 4.

12 B.C. Health Services, supra, note 1, at para. 2. 
with which five other members of the Court concurred, ${ }^{13}$ concluded "that the grounds advanced in the earlier decisions for the exclusion of collective bargaining from the Charter's protection of freedom of association do not withstand principled scrutiny and should be rejected". ${ }^{14}$

This proposition along with three others - Canada's historic recognition of the importance of collective bargaining to freedom of association, international law's understanding of collective bargaining as an integral component of freedom of association and the compatibility of a right to collective bargaining with the promotion of other Charter rights, freedoms, and values - were advanced by the majority for the conclusion that section 2(d) of the Charter protects the process of collective bargaining. Instead of examining all four propositions, I shall focus on three aspects of the Court's reasons: first, the shift from conceptualizing freedom of association as an individual to a collective right; second, the very limited positive obligation placed upon the state to protect collective bargaining; and third, the procedural, as opposed to substantive, nature of the obligation.

\section{Overturning Precedent}

In the most astonishing part of the B.C. Health Services decision, McLachlin C.J.C. and LeBel J. systematically subjected the five reasons provided in the Labour Trilogy and the subsequent decision of Professional Institute of the Public Service of Canada v. Northwest Territories (Commissioner) ("PIPSC") to critical analysis. They simply dismissed the first reason, that the rights to strike and to bargain collectively are "modern rights" created by legislation and not "fundamental freedoms", as "fail[ing] to recognize the history of labour relations in Canada", ${ }^{15}$ which they developed in their second proposition. They also dispatched the second reason, judicial deference to labour relations policy, as quickly as they did the first, claiming not only that it ignores history, but that, in addition, it takes "an overbroad view of judicial deference". ${ }^{16}$ They asserted that the third reason, "freedom of association protects only those activities performable by an individual",

\footnotetext{
13 Justice Deschamps also agreed that freedom of association included collective bargaining, but she both offered a different test for determining when that right had been violated and provided a different s. 1 analysis of what constituted a lawful infringement of the right.

14 B.C. Health Services, supra, note 1, at para. 22.

15 Id., at para. 25.

16 Id., at para. 26.
} 
was overtaken by Dunmore, where the Court recognized that certain collective activities have no individual analogue and yet are deserving of protection. ${ }^{17}$ They also rejected the fourth reason, suggested by L'Heureux-Dubé J. in PIPSC, that freedom of association was not intended to protect the objects or goals of an association. The final and overarching problem that McLachlin C.J.C. and LeBel J. identified with the majority judgments in the Labour Trilogy and PIPSC is their adoption of a decontexutalized approach to defining the scope of freedom of association, in contrast to the purposive approach taken to other Charter guarantees.

The last three reasons offered by the Court for overturning precedent most directly pertain to the aspects of the analysis of the right to bargain collectively with which I am concerned, and with the exception of the fourth reason, which hinges on the distinction between the process of collective bargaining and its substantive outcomes, they are rooted in Dunmore. According to McLachlin C.J.C. and LeBel J., Dunmore "clarified three developing aspects of the law: what constitutes interference with the 'associational aspect' of an activity; the need for a contextual approach to freedom of association; and the recognition that s. $2(d)$ can impose positive obligations on government". ${ }^{18}$

\section{Freedom to Associate: The Shift from an Individual to a Collective Right}

One of the most controversial aspects of the B.C. Health Services case is the Court's conclusion that the "narrow focus on individual activities" in the Labour Trilogy and in PIPSC "has been overtaken by Dunmore, where this Court rejected the notion that freedom of association applies only to activities capable of performance by individuals". ${ }^{19}$ In Dunmore, Bastarache J. held that "[t]o limit s. $2(d)$ to activities that are performable by individuals would ... render futile these fundamental initiatives" since, as Dickson C.J.C. noted in his dissent in the Alberta Reference, some collective activities may, by their very nature, be incapable of being performed by an individual. ${ }^{20}$

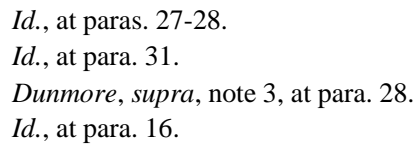


It is not precisely clear what Bastarache $\mathrm{J}$. meant by characterizing collective bargaining as a collective, and not an individual, right. Part of the problem is that he failed to distinguish between the question of who possesses the right (the individual or the collective) and the question of the conditions necessary for the right's successful exercise. ${ }^{21}$ Collective bargaining could be viewed as an individual right, in the sense that it vests in the individual worker and not in the collective, which is the trade union. But, even if it were to be considered an individual right, collective bargaining would be one of a hybrid nature, since it is a right that can only be enjoyed by individuals when it is exercised collectively. ${ }^{22}$ This characterization of the right to bargain collectively is compatible with McIntyre J.'s approach in the Labour Trilogy, which was that individuals should be entitled to do collectively what they are entitled to do singly. Since individuals have the right singly to bargain their terms and conditions of employment, they should be permitted to bargain them collectively. ${ }^{23}$ In this conception of the right to bargain collectively the individual possesses the right, but the right is collective to the extent that it can only be exercised in concert with others. It recognizes both that there is an individual analogue to collective bargaining (which is individual bargaining) and that the right vests in the individual; however, it also appreciates the qualitative difference between individual and collective bargaining. Collective bargaining, unlike individual bargaining, is essentially an associational activity. This approach is also compatible with Bastarache J.'s understanding of what Dickson C.J.C. meant in the Alberta Reference; "such activities may be collective in nature, in that they cannot be performed by individuals acting alone". ${ }^{24}$

However, at other points in his analysis Bastarache J. appears to conceive of the right to bargain collectively as a collective right in the sense that the right is vested in the collective (the union), and not in individual employees. In his dissenting judgment in the Alberta Reference, Dickson C.J.C. stated:

There will, however, be occasions when no analogy involving individuals can be found for associational activity, or when a comparison between

\footnotetext{
21 Sheldon Leader, Freedom of Association: A Study in Labor Law and Political Theory (New Haven: Yale University Press, 1992), at 35 [hereinafter "Leader"]. 
groups and individuals fails to capture the essence of a possible violation of associational rights. ${ }^{25}$

Taking this statement as his warrant, Bastarache J. went on to assert:

... the very notion of "association" recognizes the qualitative differences between individuals and collectivities. It recognizes that the press differs qualitatively from the journalist, the language community from the language speaker, the union from the worker. In all cases, the community assumes a life of its own and develops needs and priorities that differ from those of its individual members. ... [B]ecause trade unions develop needs and priorities that are distinct from those of their members individually, they cannot function if the law protects exclusively what might be "the lawful activities of individuals". ${ }^{26}$

This conception of the right to bargain collectively is essentially collective; the right vests in the collective and not in the individual. However, the problem with this approach is that it begs the deeper normative question concerning the needs and priorities of collectivities such as trade unions that ought to be constitutionally protected.

Whether the right to bargain collectively is considered to be a hybrid-individual right that can only by exercised collectively or a purely collective right has important consequences. ${ }^{27} \mathrm{~A}$ right to bargain collectively that vests in the individual would not depend upon the existence of an acceptable or officially recognized trade union. Even if the right were to vest in the individual, it would not necessarily follow that when the individual's right clashes with the collective that the individual's right would take precedence. How to resolve any conflict between the individual and the collective would depend on the rights and interests at stake and how they are exercised. However, if the right to bargain collectively is seen as vesting in the collective as an institution then the individual would not have the right to engage in collective pursuits outside of what he or she engages in through that institution. Moreover, vesting the right to bargain collectively in the collective would require some prior notion of and justification for the "acceptable" objects of unions. The problem with such an approach to the freedom to

25 Id., at para. 16, quoting Alberta Reference, id., at 367.

26 Id., at para. 17, quoted in B.C. Health Services, supra, note 1, at para. 28.

27 As Leader demonstrates, these consequences are much more important when it comes to the right to strike, and he illustrates these consequences by contrasting the case of France, where the right to strike is an individual right that vests in the workers, with that of Germany, where the right is a collective one that vests in the union: see supra, note 21 , at 183-200. 
associate is that it precludes a range of alternative collectivities through which individuals can operate. ${ }^{28}$ In effect, what it does is elevate the tenets of a particular form of industrial pluralism, in which trade unions have exclusive bargaining rights, to a constitutional right. As Sheldon Leader notes, it is also inattentive to "the increasing cleavages of fundamental interest among the workforce on some issues". ${ }^{29}$

Although it is not clear in which way the freedom to associate and the right to bargain collectively are considered to be collective rights (as a hybrid-individual or purely collective right) in the B.C. Health Services case, both the extracts that McLachlin C.J.C. and LeBel J. quote from Dunmore and their treatment of the history of collective bargaining in Canada suggest that they regard it as purely collective. Eric Tucker has demonstrated that the Court's judgment rests upon and reinforces an industrial pluralist account of the history of Canadian collective bargaining law. ${ }^{30}$

A central problem with the Court's historical analysis of collective bargaining is that it elides the different legal statuses that the activity of collective bargaining has had at different periods of time. Although workers engaged in the activity of collective bargaining back in the early 1800 s, until 1872 it was, at the very least, potentially criminal activity. By the early 1900s, workers were free to bargain collectively in the sense that the state did not prohibit the activity. But collective bargaining only became a legal right in the mid-1940s when the state imposed a legal duty on employers to bargain in good faith with a certified trade union. ${ }^{31}$ Thus, while it is true that the social practice of collective bargaining has long been recognized, it does not follow from this observation that collective bargaining as a procedural right backed by the duty to bargain in good faith has long been recognized. The Court has attempted to construct a linear narrative of the history of Canadian labour law in which the immanent right to bargain collectively was realized during the Second World War with the advent of a Wagnerbased model of collective bargaining legislation. ${ }^{32}$ If the Canadian variety of majority-based, exclusive union representation backed by an

\footnotetext{
28 Id., at 205.

29 Id., at 269. Two-tier wage schemes, in which employees with shorter service than those with longer tenure receive less wages, and conflicts between workers who are parents of young children and those who are not are examples of such cleavages. Tucker, supra, note 6.

Id.

B.C. Health Services, supra, note 1, at para. 68 .
} 
obligation imposed upon employers to bargain in good faith is taken as the apotheosis of the right to bargain collectively then the right is a collective right since the right vests in the duly certified or recognized trade union and not in the individual worker.

\section{The Limited Scope of the Positive Duty to Protect Collective Bargaining}

The fifth reason McLachlin C.J.C. and LeBel J. offered for overturning the narrow interpretation of the freedom to associate provided in the Labour Trilogy and PIPSC is the need to adopt a contextual approach. Once again they put great store in Dunmore, which recognized that section 2(d) may place positive obligations on the government to extend legislation to particular groups. However, they were also careful to emphasize the limitations expressed in Dunmore on the scope of this positive duty; "there must be evidence that the freedom would be next to impossible to exercise without positively recognizing a right to access a statutory regime". ${ }^{33}$

The limited scope of the state's obligation to provide protections for collective bargaining has its roots in the Supreme Court's commitment to ensuring that the Charter only directly applies to governmental or public action. While there is a great deal of indeterminacy about what counts as public action in order to trigger the application of the Charter, the Supreme Court of Canada has continued to maintain its position, first articulated in Dolphin Delivery, that common law litigation between private parties is outside the purview of the Charter. ${ }^{34}$ What this restriction means in the employment context is that employers can use their common law rights enforced by judge-made common law doctrines to interfere with workers' freedom to join unions and unions' right to bargain collectively without having to worry that the Charter will unduly restrict them. ${ }^{35}$

\footnotetext{
33 Id., at para. 34.

R.W.D.S.U. v. Dolphin Delivery Ltd., [1986] S.C.J. No. 75, [1986] 2 S.C.R. 573 (S.C.C.). 35 R.W.D.S.U., Local 558 v. Pepsi-Cola Canada Beverages (West) Ltd., [2002] S.C.J. No. 7, [2002] 1 S.C.R. 156 (S.C.C.), the Supreme Court of Canada interpreted the common law restrictions on picketing in light of Charter values and disavowed the common law tort that rendered secondary picketing per se illegal. However, as the Court noted, there is a plethora of torts that can be used to limit the scope of picketing.
} 


\section{The Right to Bargain Collectively as Purely Procedural}

The fourth reason that McLachlin C.J.C. and LeBel J. gave for departing from precedent was their rejection of L'Heureux-Dubé J.'s suggestion in PIPSC that freedom of association was not intended to protect the objects or goals of an association. Instead, they developed a distinction - between a procedure and its substantive outcome - that is a crucial element in their positive definition of the right to bargain collectively. In contradistinction to L'Heureux-Dubé J. they claimed that it will always be possible to characterize the pursuit of a particular activity in concert with others as the "object" of that association. However, they acknowledged that her "underlying concern - that the Charter not be used to protect the substantive outcomes of any and all associations - is a valid one". ${ }^{36}$ Invoking an early article by Bora Laskin - the grandfather of Canadian labour law and a former Chief Justice of the Supreme Court of Canada - in support of their preferred distinction, McLachlin C.J.C. and LeBel J. declared that "collective bargaining' as a procedure has always been distinguishable from its final outcomes (e.g., the results of the bargaining process, which may be reflected in a collective agreement)" ${ }^{37}$ Thus, they concluded "it is entirely possible to protect the 'procedure' known as collective bargaining without mandating constitutional protection for the fruits of that bargaining process." 38

\section{Substantive Equality and the Right to Bargain Collectively}

Having made the negative case for overturning precedent, McLachlin C.J.C. and LeBel J. resort to history, international law and Charter values to make the positive case that collective bargaining is protected by the constitutional guarantee of freedom of association. They identify equality as one of the Charter values that the right to bargain collectively promotes:

Collective bargaining also enhances the Charter value of equality. One of the fundamental achievements of collective bargaining is to palliate

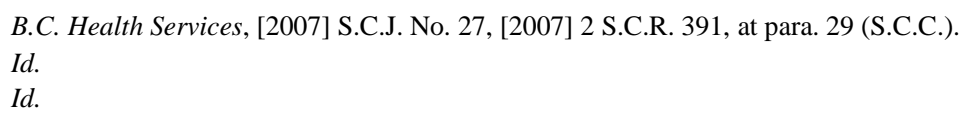


the historical inequality between employers and employees: see Wallace v. United Grain Growers Ltd., per Iacobucci J. ${ }^{39}$

Moreover, it is clear that the Court is endorsing a substantive conception of economic inequality, since McLachlin C.J.C. and LeBel J. quote from Dickson C.J.C.'s dissent in the Alberta Reference:

Freedom of association is the cornerstone of modern labour relations. Historically, workers have combined to overcome the inherent inequalities of bargaining power in the employment relationship and to protect themselves from unfair, unsafe, or exploitative working conditions. ${ }^{40}$

The goal of fostering substantive equality could function as the normative basis for grounding a purely collective right to freely associate that vests in trade unions. However, in order to do so, the Court would need to provide a more detailed account of what constitutes inequality of bargaining power and the extent to which that inequality should be remedied. But instead of developing substantive equality as the normative basis for the constitutionally protected right to bargain collectively, the Court goes on to develop a very thin conception of the right from which a substantive vision of equality is virtually absent.

\section{A Thin Conception of the Right to Bargain Collectively}

Having made the positive case for recognizing a right to bargain collectively, McLachlin C.J.C. and LeBel J. proceed to explain what this right entails. In light of the judgment's expansive rhetoric extolling collective bargaining as tantamount to a fundamental human right, what is striking is just how limited the right is. First, the Charter only applies to state action, that is, to legislation or to the government as an employer. The Charter does not apply to private employers directly. To succeed in arguing that under-inclusive legislation violates freedom of association, a claimant would have to demonstrate "the freedom would be next to impossible to exercise without positively recognizing a right to access a statutory regime". ${ }^{41}$ In Dunmore, the Supreme Court held that the state had a positive duty to enact legislation to protect workers'

\footnotetext{
$39 \quad I d$., at para. 84. (S.C.C.).

Id., quoting Alberta Reference, [1987] S.C.J. No. 10, [1987] 1 S.C.R. 313, at 334 (S.C.C.).

Id., at para. 34 referring to Dunmore, [2001] S.C.J. No. 87, [2001] 3 S.C.R. 1016
} 
Charter rights if the party seeking the legislative protection could establish an evidentiary foundation that without legislative protection the workers would not be able to enjoy, form, join and participate in trade unions. ${ }^{42}$ Nothing in Dunmore requires the state to provide collective bargaining legislation where there is none. ${ }^{43}$ Second, section $2(\mathrm{~d})$ does not guarantee the particular objectives sought through associational activity, only the process through which those goals are pursued. Third, the Charter does not protect all aspects of the associational activity of collective bargaining. It protects only against "substantial interference" with associational activity. Invoking Dunmore as support, McLachlin C.J.C. and LeBel J. assert "the state must not substantially interfere with the ability of a union to exert meaningful influence over working conditions through a process of collective bargaining conducted in accordance with the duty to bargain in good faith". ${ }^{44}$ Fourth, McLachlin C.J.C. and LeBel J. were very careful to state that the right to collective bargaining protected by section $2(\mathrm{~d})$ of the Charter is a limited right; "the right is to a general process of collective bargaining, not to a particular model of labour relations, not to a specific bargaining method" ${ }^{45}$ The Court did not consider modifications to collective bargaining legislation to violate section 2(d). Thus, despite the bold statement at the beginning of judgment "that the s. 2(d) guarantee of freedom of association protects the capacity of members of labour unions to engage in collective bargaining on workplace issues", the actual "right to collective bargaining $\ldots$ is a limited right". ${ }^{46}$

The scope of the constitutionally protected right to bargain collectively hinges on what substantial interference with the process of

42 Justice Bastarache concluded that the repeal of legislation extending labour legislation to agricultural workers was a signal to employers that they did not have to respect the workers' fundamental rights.

43 Nevertheless, it may be difficult for the state to repeal collective bargaining legislation in the private sector entirely without putting anything in its place since this action could be considered a signal to employers to interfere with workers' fundamental rights. At the very least, in the private sector some restrictions on employers' exercise of their civil rights (such as to discharge employees for being union members) would seem to be warranted. In the public sector, since the employer is a state actor, there may be a more robust duty to bargain, perhaps even with unions representing less than a majority of workers. My thanks to Eric Tucker for the latter observation.

$44 \quad$ B.C. Health Services, supra, note 36, at para. 90.

$45 \quad$ Id., at para. 91.

46 Id., at paras. 2 and 91. Despite the Court's care in delineating how restrictive the constitutionally protected right to bargain collectively is, some commentators have asserted "it is clear that the Court's collective bargaining scheme will impose substantial burdens on public sector employers". Cameron, supra, note 5, citing Charney, supra, note 5. 
collective bargaining means. Chief Justice McLachlin and LeBel J. went on to elaborate that substantial interference is to be assessed on two bases, both of which are essential: (1) the importance of the matter affected to the process of collective bargaining, and (2) the manner in which the measure impacts on the collective right to good faith negotiation and consultation. The essential question relating to the first basis is whether the subject matter of the particular instance of collective bargaining is such that interfering with bargaining over it will affect the ability of unions to pursue common goals effectively. While not determinative of this inquiry, the majority asserted that the more important the matter is to a union and its members, the more likely there is substantial interference with a section 2(d) right. ${ }^{47}$

Once it is established that the government action impacts on a subject matter important to collective bargaining, then the second basis for determining substantial interference comes into play: does the state action respect the duty to consult and negotiate in good faith? In attempting to give this notoriously vague and indeterminate duty some content, the majority refers to ILO principles concerning collective bargaining, the Canada Labour Code and provincial labour relations legislation, remarks made by Senator Walsh in the Senate Committee hearings on the Wagner Act, academic commentators and Supreme Court judgments. ${ }^{48}$ The result is a confusing mishmash, in which the procedural aspect of the duty is emphasized, although a court's right to evaluate the substance of negotiations in determining whether the duty of good faith had been met is reaffirmed. Further complicating matters, the majority introduces factors more appropriate to the section 1 analysis, which addresses whether the infringement of the right is justified, into the determination of whether section 2(d) has been breached. According to McLachlin C.J.C. and LeBel J., the circumstances surrounding the adoption of legislative provisions, such as situations of exigency and urgency, may "affect the content and modalities of the duty to bargain in good faith". ${ }^{49}$ However, these are the same factors that are considered in the determination of the justification for the violation. In fact, in the very next paragraph, they state that section 1 "may permit interference with the collective bargaining process

\footnotetext{
47 The examples the Court provided were laws or state actions that prevent meaningful discussion or consultation about working conditions or that nullify significant negotiated terms in existing collective agreements.

48 B.C. Health Services, supra, note 36, at paras. 97-107.

$49 \quad$ Id., at para. 107.
} 
on an exceptional and typically temporary basis, in situations, for example, involving essential services, vital state administration, clear deadlocks and national crisis". ${ }^{50}$

Thus, the Court's commitment to furthering substantive economic equality through providing constitutional protection for the right to bargain collectively is belied by its articulation of what the right actually comprises. It is difficult to see how a purely procedural right to bargain collectively that is backed by an obligation on an employer to bargain in good faith can address substantive inequality in bargaining power unless such a right is reinforced by a dispute resolution procedure such as the right to strike. The extent of the gap between the Court's rhetoric of substantive equality and the reality of the legal holding that implements it is, as we shall see in the following part, clearly manifest in McLachlin C.J.C. and LeBel J.'s dismissive treatment of the unions' equality argument in the B.C. Health Services case.

\section{EQUALITY AT WORK}

\section{The Supreme Court of Canada's Approach to Equality under the Charter ${ }^{51}$}

Equality is a contested concept that involves competing social values. It can be informed by the values of traditional liberalism, such as individualism and freedom, and understood in a formal sense as consistency in treatment, or it can be infused with the social democratic values, such as solidarity and welfare, which are aligned with substantive equality. ${ }^{52}$ The openness and generality of the language of equality requires courts to identify and to elaborate the values that equality serves.

In 1989 the Supreme Court of Canada issued its first decision interpreting equality rights, Law Society of British Columbia $v$. Andrews ${ }^{53}$ which became the touchstone for substantive equality. Writing for the majority, McIntyre J. adopted a comparative and

$50 \quad$ Id., at para. 108.

51 This section and the one that follows are based upon Judy Fudge, "Substantive Equality, the Supreme Court of Canada, and the Limits to Redistribution" (2007) 23 (2) S.A.J.H.R. 235-53 [hereinafter "Fudge"].

52 Gavin Anderson, "Social Democracy and the Limits of Rights Constitutionalism" (2004) 17 Can. J.L. \& Jur. 31; Colleen Sheppard, "Inclusive Equality and New Forms of Social Governance" (2004) 24 S.C.L.R. (2d) 45, at 57-63 [hereinafter "Sheppard"].

53 [1989] S.C.J. No. 6, [1989] 1 S.C.R. 143 (S.C.C.) [hereinafter "Andrews"]. 
substantive approach to the guarantee of equality in section 15 that was directed to prohibiting discrimination. Although his decision was lauded both for rejecting the similarly situated approach and for placing the burden for justifying the legislative distinction on the party seeking to uphold the legislation, his notion of discrimination lacked a substantive focus on inequalities entrenched in social and historical practices, norms and attitudes. Instead, he favoured an individualized and decontextualized approach that focused on the distinction between individual merit and capacities, on the one hand, and, on the other, irrelevant stereotypes. ${ }^{54}$

After Andrews, the Supreme Court of Canada became deeply divided on how to interpret substantive equality. ${ }^{55}$ The question was what kind of legislative distinction was to count as discrimination. This question is contentious, and courts have many choices that they must make and justify when deciding cases involving the Charter's equality rights. In an article entitled "Equality: The Most Difficult Right", McLachlin C.J.C. described equality as a Tantalus promising "more than it can deliver". 56 She warned, "absolute substantive equality is impossible" because of "the diversity of our society and its foundation in the competition of the marketplace". ${ }^{57}$ Thus, the exercise is one of drawing limits to substantive equality. According to her:

A market-based representative democracy necessarily tolerates a certain degree of disparity, economic and otherwise. It is perhaps for this reason that the Canadian equality experience, expressed in human rights legislation as well as in the enumerated grounds of section 15, focuses on particular sources of inequality that have historically proven unjust and harmful to the affected individuals and to society as a whole. ${ }^{58}$

The Court sees rectifying the situation of disadvantaged groups as the central goal of equality rights in the Canadian Charter.

\footnotetext{
54 This analysis of Andrews, id., draws upon research that I am conducting with my colleague Hester Lessard on the shifting meaning of equality in Canadian jurisprudence.

$55 \quad$ William Black \& Lynn Smith, "The Equality Rights" (2005) 27 S.C.L.R. (2d) 315; Peter Hogg, "What Is Equality? The Winding Course of Judicial Interpretation" (2005) 29 S.C.L.R. (2d) 39 [hereinafter "Black \& Smith"]; Sheilah Martin, "Balancing Individual Rights to Equality and Social Goals" (2001) 80 Can. Bar Rev. 299 [hereinafter "Martin"].

56 Beverley McLachlin, "Equality: The Most Difficult Right" (2001) 14 S.C.L.R. (2d) 17, at 20. This article was written before Justice McLachlin became Chief Justice.

$57 \quad I d$.

$58 \quad I d$., at 20-21.
} 
But the more difficult question, according to McLachlin C.J.C., is "whether, and if so, to what extent, [the ambit of the equality guarantee] should apply outside its traditional discrimination-oriented focus". ${ }^{59}$ This difficulty arises because:

The Charter positively accords Canadians equal benefit of the law and equal protection from the law's burden. This can be argued to extend the guarantee of equality to matters beyond the scope of traditional anti-discrimination law, to equal provision of state benefits, even when the group excluded is not the object of historic discrimination. ${ }^{60}$

The question here is whether the state's "largesse has been appropriately distributed"; but, as the Chief Justice acknowledged, the problem is that the goal of equality in this context is less clear. ${ }^{6}$

In 1999 in Law v. Canada (Minister of Employment and Immigration), ${ }^{62}$ a unanimous Supreme Court of Canada adopted an approach to equality that focused on the goal of protecting human dignity. Justice Iacobucci set out what has become the authoritative approach to interpreting the equality rights in section 15 . He identified the purpose of section 15 as preventing

... the violation of human essential dignity and freedom through the imposition of disadvantage, stereotyping, or political or social prejudice, and to promote a society in which all persons enjoy equal recognition at law as human beings or members of Canadian society, equally capable and equally deserving of concern, respect and consideration. ${ }^{63}$

He also confirmed that the Court would continue to take the comparative approach to equality that it adopted in Andrews; "[u]ltimately, a court must identify differential treatment as compared to one or more persons or groups. ${ }^{964}$

The equality framework set out in Law involves three stages and the claimant has the burden at each stage. Only after the claimant has satisfied all of the three stages does the government have the burden of justifying the violation under section 1 . The first inquiry focuses on the law or the impugned state action in order to determine whether it draws a distinction between the claimant and others on the basis of some

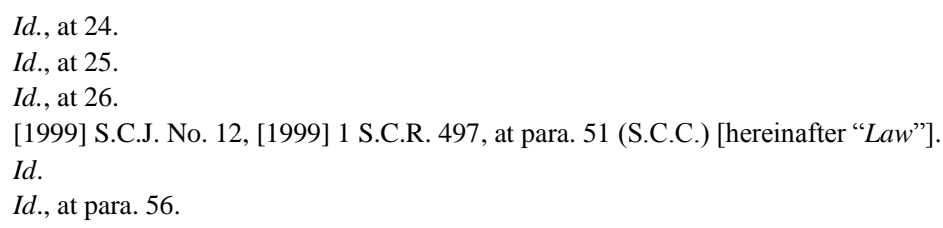


personal characteristics or fails to take account of a disadvantaged position resulting in differential treatment. There are two components of this stage - a distinction drawn by law and a difference in treatment compared to another group. At this stage it is necessary to identify a comparator in relation to which the claimant can properly claim unequal treatment. In the second stage the target of the inquiry is how the legislation is related to the prohibited grounds of discrimination or to a ground that is analogous to a prohibited ground. The third stage is an inquiry into the nature of the harm in order to determine whether there has been discrimination in a substantive sense. The focus is on whether the differential treatment harms or impairs the claimant's dignity and Iacobucci J. set out four contextual factors to assist in this stage. These factors are: (1) the social disadvantage of the group represented by the claimant; (2) the correspondence between legislative distinctions and that actual need, capacity, or circumstances of the claimant; (3) the ameliorative purpose or effects of the impugned legislation on a more disadvantaged group; and (4) the nature of the claimant's interest. The first and fourth factors go to the harm suffered by the claimant - the indignity, whereas the second and third factors save the legislation. ${ }^{65}$

The effect of this framework for evaluating equality claims has been to restrict the redistributive impact of section 15. At the first stage a claimant must establish differential treatment under the law $^{66}$ and at the second stage the claimant must establish that the differential treatment is on the basis of an enumerated or analogous ground. ${ }^{67}$

Identifying the appropriate comparator is necessary for identifying differential treatment and the grounds of the distinction, and it is relevant when considering many of the contextual factors in the discrimination analysis. The question of the appropriate comparator is up to the Court to decide, and it identifies the comparator on the basis of the subject matter of the legislation and "biological, historical, and sociological similarities or dissimilarities" between the claimant and others. ${ }^{68}$ Disputes about the

65 Hester Lessard, "Mothers, Fathers, and Naming: Reflections on the Law Equality Framework and Trociuk v. British Columbia (Attorney General)" (2004) 16 C.J.W.L. 165, at 17374.

66 Auton (Guardian ad litem of) v. British Columbia (Attorney General), [2004] S.C.J. No. 71, [2004] 3 S.C.R. 657 (S.C.C.).

67 The Court has recognized sexual orientation, marital status and citizenship as analogous grounds: see Black \& Smith, supra, note 55, at 397-414.

68 Law, supra, note 62, at paras. 56-58, 90; Granovsky v. Canada (Minister of Employment and Immigration), [2000] S.C.J. No. 29, [2000] 1 S.C.R. 703, at paras. 47, 52, 64 (S.C.C.); Auton, 
relevant pool for comparison reveal disagreements about whether equality requires merely equal treatment or whether it aspires to a greater ambition to achieve a more equal distribution. ${ }^{69}$

Moreover, the effect of interpreting equality through the lens of dignity has been to focus on discrimination and to narrow the ambit of substantive equality. So far the Court's approach to dignity has tended to emphasize self-worth and integrity and to downplay material and systemic factors in determining whether equality rights have been violated. ${ }^{70}$ It has viewed equality claims through an identity-based recognition framework that displaces redistributive claims. ${ }^{71}$ The Court has also adopted a "reasonable person standard" for the determination of whether the distinction that disadvantages the claimant as compared to another group violates the claimant's dignity. ${ }^{72}$

Thus, while it is true that substantive equality entails a departure from the treatment of equality rights as negative rights and its remedies can include the extension both of benefits and legal protections, ${ }^{73}$ the

supra, note 66; Hodge v. Canada (Minister of Human Resources Development), [2004] S.C.J. No. 60, [2004] 3 S.C.R. 357 (S.C.C.).

69 Catherine Barnard \& Bob Hepple, "Substantive Equality" (2000) 59 Cambridge L.J. 562.

70 Gwen Brodsky, "Gosselin v. Quebec (Attorney General): Autonomy with a Vengeance" (2003) 15 C.J.W.L. 194, at 212; Sheppard, supra, note 52, at 50; Martin, supra, note 55, at 329.

71 It is not inevitable that recognition displaces redistribution since recognition can be seen in terms of status subordination and not only identity misrecognition; see Judy Fudge, "The Canadian Charter of Rights: Recognition, Redistribution, and the Imperialism of the Courts" in Tom Campbell, Keith Ewing \& Adam Tomkins, eds., Sceptical Essays on Human Rights (Oxford: Oxford University Press, 2002), at 335.

72 In Law, supra, note 62, at para. 61, the Court specified that a subjective-objective standard should be used in assessing an injury to dignity. However, the Court has subsequently moved to an objective or reasonable person standard. See Lovelace v. Ontario, [2000] S.C.J. No. 36, [2000] 1 S.C.R. 950 (S.C.C.). Recently, in R. v. Kapp, [2008] S.C.J. No. 42, 2008 SCC 41 (S.C.C.), the Supreme Court of Canada recognized the legitimacy of the criticisms of the use of dignity both in and after Law and reaffirmed the two-step approach to equality set out in Andrews, supra, note 53.

73 Schachter v. Canada, [1992] S.C.J. No. 68, [1992] 2 S.C.R. 679 (S.C.C.) addressed the issue of the appropriate remedy for discriminatory benefits. In Eldridge v. British Columbia (Attorney General), [1997] S.C.J. No. 86, [1997] 3 S.C.R. 624 (S.C.C.) the Court ordered the government of British Columbia to provide interpreter services for deaf patients who were using hospital services. In Vriend v. Alberta, [1998] S.C.J. No. 29, [1998] 1 S.C.R. 493 (S.C.C.) the Court ordered the inclusion of sexual orientation as a prohibited ground of discrimination in Alberta's anti-discrimination legislation. In Nova Scotia (Workers' Compensation Board) v. Martin, [2003] S.C.J. No. 54, [2003] 2 S.C.R. 504 (S.C.C.) the Court held that the denial of benefits to sufferers of chronic pain was discriminatory and ordered that benefits be provided to them. However, in Canada (Attorney General) v. Hislop, [2007] S.C.J. No. 10, [2007] 1 S.C.R. 429 (S.C.C.) a unanimous Supreme Court of Canada adopted a new approach to remedies for the violation of Charter protected-equality rights, denying the surviving same-sex spouses fully retroactive pension benefits. The Supreme Court's restrictive approach to remedies for breaches of equality rights is discussed in Cristin Schmitz, "Top court's restriction of Charter remedies seen as a major shift" The Lawyers Weekly, March 16, 2007, vol. 25, number 42, at 24. 
redistributive potential of equality rights is quite small. ${ }^{74}$ It is important to remember that the majority of equality claims have been unsuccessful. ${ }^{75} \mathrm{In}$ cases involving equality rights claims that directly target the ways in which governments raise and distribute material resources in areas such as income tax, pension, or social assistance policy it is rare that the claimant is able to establish discrimination. ${ }^{76}$

\section{Newfoundland $v$. NAPE: "More than just a matter of dollars and cents"}

In light of the fact that redistributive claims are rarely successful under section 15, Newfoundland v. NAPE was an unusual case. ${ }^{78}$ It was the first equality case brought by women in which the Supreme Court of Canada held that the Charter's equality guarantees had been violated. ${ }^{79}$ But it was also the first equality case in which the Court justified the violation of equality rights solely on economic grounds.

In 1988 the Government of Newfoundland and Labrador signed a pay equity agreement with five of its public sector trade unions that was designed to equalize the wages of women and men who performed work of the same value. ${ }^{80}$ Three years later when the government and the

\footnotetext{
74 Margot Young, "Change at the Margins: Eldridge v. British Columbia and Vriend v. Alberta" (1998) 10 C.J.W.L. 244.

75 Sheila McIntyre, "The Supreme Court and Section 15: A Thin and Impoverished Notion of Judicial Review" (2006) 31 Queen's L.J. 731, at 742-45. McIntyre looked at the results of the equality cases since Law.

Bruce Ryder, Cecilia Faria \& Emily Lawrence, "What's Law Good For?: An Empirical Overview of Charter Equality Decisions” (2004) 24 S.C.L.R. (2d) 103, at 126.

77 [2004] S.C.J. No. 61, [2004] 3 S.C.R. 381, at para. 40 (S.C.C.), per Binnie J. He quoted the now notorious dissent of Dickson C.J.C. in the Alberta Reference, [1987] S.C.J. No. 10, [1987] 1 S.C.R. 313, at 368 (S.C.C.) that "[w]ork is one of the most fundamental aspects in a person's life."

78 However, from the perspective of wage control legislation, Newfoundland v. NAPE is typical. The Supreme Court of Canada had previously decided that legislation revoking collective bargaining rights and ignoring collective agreements as a response to a financial emergency was constitutional: see Reference re Anti-Inflation Act (Canada), [1976] S.C.J. No. 12, [1976] 2 S.C.R. 373 (S.C.C.); Public Service Alliance of Canada v. Canada, [1987] S.C.J. No. 9, [1987] 1 S.C.R. 424 (S.C.C.).

79 Patricia Hughes, "Case Comment: Newfoundland (Treasury Board) v. N.A.P.E." (2004) 11 C.L.E.L.J. 16, n. 47. It is also one of the two equality cases after Law in which the Court used s. 1 to uphold legislation that violated equality. The other case was Lavoie v. Canada, [2002] S.C.J. No. 24, [2002] 1 S.C.R. 769 (S.C.C.), in which the federal civil service hiring preference in favour of Canadian citizens was held to be discriminatory but justified.

80 Pay equity is the term used in Canada for equal pay for work of equal value strategies. The purpose of pay equity is to redress the historical undervaluation of work that has traditionally been performed by women.
} 
unions finally agreed upon the wage adjustments necessary to achieve pay equity, the government claimed that it was in a financial crisis. As part of a series of measures to deal with the provincial deficit, the government enacted public sector wage restraint legislation that cancelled the $\$ 24$ million in pay equity wage adjustments that it owed to the women employed in the province's health care sector.

The Newfoundland Association of Public Employees ("NAPE"), which represented the predominantly female health care workers, managed to navigate successfully through the maze of equality jurisprudence; however, it was stymied at the section 1 stage. In 2004, a unanimous seven-member bench of the Supreme Court of Canada upheld the legislation cancelling the pay equity debt on the ground that the province's financial crisis justified violating the (predominantly women) workers' equality rights.

Justice Binnie began his equality analysis by noting " $[\mathrm{t}]$ he value placed on a person's work is more than just a matter of dollars and cents". ${ }^{81}$ Starting from this premise, he concluded that this case "fits easily within the framework established in Law v. Canada ... which identified the affirmation of human dignity and self-worth as a central purpose of s. 15(1) of the Charter" ${ }^{82}$ He found that the wage control legislation drew a formal distinction between those who were entitled to benefit from pay equity and everyone else; that the appropriate comparator group consisted of men in male-dominated classifications performing work of equal value; and that the differential treatment arose not merely because of the type of job, but rather because the job is one generally held by women. Having concluded that the first two steps of the Law analysis were fulfilled - a distinction resulting in a disadvantage in relation to a comparator group and a prohibited ground (in this case sex) - he moved on to consider whether the distinction amounted to discrimination in light of the four contextual factors set out in Law.

The analysis of the first three factors was straightforward. What is interesting is Binnie J.'s treatment of the fourth factor - the nature of the claimant's interest. The fact that the women workers were paid less than what their work was worth and that this low pay would translate into lower pensions was not of sufficient importance to merit constitutional protection. What was needed was some infringement of the women workers' dignity. According to him, "[l] ow pay often denotes

\footnotetext{
81 Newfoundland v. NAPE, supra, note 77, at para. 40.

$82 \quad$ Id., at para. 41.
} 
low status jobs, exacting a price in dignity as well as dollars". ${ }^{83}$ Thus he concluded that the wage restraint legislation violated the women workers' equality rights, and in doing so he transformed a distributive claim into one involving dignity.

However, despite his ringing endorsement of equality rights and the declaration that the Court must act as the referee who determines the boundaries of the legal exercise of state power, Binnie J. found that the provincial legislation was a demonstrably justified limitation of the women workers' equality rights. His section 1 analysis demonstrates how easy it is for a government to override equality rights in the name of fiscal crisis. All the government has to do is declare a fiscal crisis in the legislature and the courts will take judicial notice of the emergency and defer to the government's judgment in balancing women's equality rights against competing social values. ${ }^{84}$

\section{Equality in the B.C. Health Services Case: Nothing Personal}

In the B.C. Health Services case, the unions' equality challenge emphasized the fact that employment in the health services sector is female dominated and that women's work has historically been undervalued in order to engage the right to equality protected in section 15. Here the main hurdle was the Law test. The specific difficulty facing the health services unions was to persuade the various levels of courts that the gendered nature of health service occupations could function as a personal characteristic that could ground a claim of discrimination. With the exception of L'Heureux-Dubé J.'s separate concurring reasons in Dunmore and an offhand remark by the majority in Delisle - two cases that dealt with freedom of association and collective bargaining for workers who were excluded from statutory schemes - there is no authority for the proposition that occupational status may be recognized as an analogous ground. ${ }^{85}$

The health care unions urged the British Columbia Supreme Court to adopt a remedial and purposive approach to section 15, which assessed section 15 claims on a "contextual, flexible basis from the perspective of

\footnotetext{
$83 \quad I d$., at para. 49.

84 See the discussion in Fudge, supra, note 51, at 248-51.

85 Dunmore, [2001] S.C.J. No. 87, [2001] 3 S.C.R. 1016, at para. 167 (S.C.C.); Delisle v. Canada (Deputy Attorney General), [1999] S.C.J. No. 43, [1999] 2 S.C.R. 989, at para. 44 (S.C.C.) [hereinafter "Delisle"].
} 
the claimant". ${ }^{86}$ As part of the "contextual matrix" the unions emphasized the disadvantage women suffer in employment, the prejudice and stereotyping attached to "women's work", and the importance of unionization and collective bargaining in overcoming this disadvantage. ${ }^{87}$ With respect to the first step of the Law test, the plaintiff unions and health-care workers argued that occupational status is a personal characteristic central to one's identity and sense of self and that by targeting health care workers Bill 29 failed to take account of the plaintiffs' already disadvantaged status, which resulted in substantially different treatment between the plaintiffs and others on the basis of sex and working in a female-dominated occupational sector. They also identified the appropriate comparator group, which is the second element of the first step, as public sector workers who do not work in the most female-dominated sectors. ${ }^{88}$ Regarding the second step of the Law equality framework, the plaintiffs argued that the health care workers were disadvantaged on the basis of their sex, an enumerated ground, and the analogous ground of women's jobs since only health care workers were targeted by the legislation, and that such workers are predominantly female. ${ }^{89}$ They also argued that the third step of the Law test was fulfilled since Bill 29 denied the benefit of collective bargaining only to health care workers and that this drew a distinction on the basis of a personal characteristic and perpetuated the view that these workers are not as deserving of respect and consideration as other unionized workers. ${ }^{90}$

To begin her analysis of the health care workers and unions' equality claim, Garson J. set out the three broad inquiries of the Law framework, and emphasized the need to adopt a purposive and contextual approach. She also stressed the comparative aspect of the equality analysis, and insisted that it was up to the court to determine the appropriate comparator.

Although Garson J. of the British Columbia Supreme Court accepted both the unions' evidence that the majority of workers affected by Bill 29 were women and were disproportionately members of visible minority groups and the undisputed evidence given by the plaintiff's expert Pat Armstrong that women's work is subject to systemic discrimination and

\footnotetext{
86 Health Services and Support-Facilities Subsector Bargaining Assn. v. British Columbia, [2003] B.C.J. No. 2107, 19 B.C.L.R. (4th) 37, at para. 152 (B.C.S.C.).

87 Id.

$88 \quad$ Id., at para. 153.

$89 \quad I d$. , at para. 154.

$90 \quad I d$. , at para. 155.
} 
undervaluation, ${ }^{91}$ it was clear that she was not amenable to the section 15 claim. The key problem was that she did "not see how Bill 29 draws a distinction between the plaintiffs and the comparator group on the basis of personal characteristics". ${ }^{92}$ According to her, the relevant comparator group was unionized public sector workers outside of the health care sector. ${ }^{93}$ She concluded that the distinction being drawn in Bill 29 "is simply between different sectors within the broader public sector; it is not based upon the personal characteristics of the employees within these sectors". ${ }^{94}$ Moreover, she went on to declare:

I do not consider the status of the plaintiffs as health care workers to be a personal characteristic. This is particularly so given the broad and disparate occupational classification that health care workers encompass and because one's personal choice [of occupation] is not an immutable characteristic. $^{95}$

Thus, the unions' claim failed both aspects of the first step of the Law test.

There are at least two problems with Garson J.'s analysis of the first stage of the Law framework. The first is her failure to appreciate the extent to which labour markets use ascribed characteristics, such as sex, race and ethnicity, to allocate individuals to specific types of jobs. Labour market analysts, especially those who study labour market segmentation (how labour markets are composed of non-competing sectors with profoundly different terms and conditions of employment and job ladders) have demonstrated how personal characteristics such as sex and race are used as markers by firms to allocate employment opportunities and to justify difference in employment terms. ${ }^{96}$ Since specific kinds of

\footnotetext{
91 Id., at para. 161. In 2003, 85 per cent of Hospital Employees Union ("HEU”) members were women, 90 per cent of British Columbia Government Employees Union ("BCGEU") members in the community sector were women, and 27 per cent of HEU members self-identified as visible minorities compared with 18 per cent of British Columbians as a whole.

92 Id., at para. 164 (emphasis in original).

93 She also had difficulty with the unions' choice of comparator group as public sector workers who do not work in the most female dominated sectors because, according to her, it is a comparator group that has the basis of the s. 15 claim infused into its description. Id., at para. 164.

$94 \quad I d$. , at para. 173.

95 Id.

96 For two classic texts, see C. Craig et al., Labour Market Structure, Industrial Organization and Low Pay. Department of Applied Economics Occasional Paper 54 (Cambridge: Cambridge University Press, 1982) and Frank Wilkinson, ed., The Dynamics of Labor Market Segmentation (New York, Academic Press, 1981). For a discussion of labour market segmentation theories in a Canadian context see Gillian Creese, Contracting Masculinity: Gender, Class, and Race in a White-Collar Union, 1944-1994 (Toronto: Oxford University Press, 1999).
} 
jobs are readily available to specific types of workers, such workers tend to "choose" these jobs. However, this choice is shaped by broader institutional factors, institutional factors that are, in turn, the residue of a legacy of historical discrimination.

The second, and more troubling, problem is that Garson J. has simply failed to appreciate the extent to which facially neutral distinctions have an adverse impact on individuals on the basis of personal characteristics. The Supreme Court of Canada recognized adverse impact discrimination in 1985 in O'Malley. $^{97}$ Moreover, in Meiorin the Supreme Court recognized that adverse impact analysis was not necessarily confined to minority groups; in that case the Court accepted that a physical fitness standard designed for men had a discriminatory impact on women, despite the fact that some women met the test, and some men did not. ${ }^{98}$ While it is true that the Supreme Court adopted the concept of adverse-effect discrimination in the context of interpreting human rights legislation, and not the equality rights in the Charter, it is unclear why this concept is inapposite to establishing the first step in the Law approach to discrimination. ${ }^{99}$ The British Columbia government

97 Ontario (Human Rights Commission) v. Simpsons Sears Ltd., [1985] S.C.J. No. 74, [1985] 2 S.C.R. 536 (S.C.C.).

98 British Columbia (Public Service Employee Relations Commission) v. BCGSEU, [1999] S.C.J. No. 46, [1999] 3 S.C.R. 3 (S.C.C.).

99 The concurring decision of Abella J. in McGill University Health Centre (Montreal General Hospital) v. Syndicat des employés de L'Hôpital général de Montréal, [2007] S.C.J. No. 4, [2007] 1 S.C.R. 161 (S.C.C.), suggests that some members of the Supreme Court of Canada want to raise the threshold for establishing discrimination in the context of human rights legislation. Justice Abella (with McLachlin C.J.C. and Bastarache J. concurring) rejected the majority's conclusion that the case turned on the question of accommodation. Rather, she declared that the pivotal issue was whether the grievor had established prima facie discrimination, shifting the onus to the employer to justify its workplace standard or conduct. In effect, she imposed an additional step on complainants in order to establish a prima facie case of discrimination. According to her, "[n]ot every distinction is discriminatory. It is not enough to impugn an employer's conduct on the basis that what was done had a negative impact on an individual in a protected group ... It is the link between that group membership and the arbitrariness of the disadvantaging criterion or conduct, either on its face or in its impact, that triggers the possibility of a remedy. And it is the claimant who bears this threshold burden" (at para. 49). What is particularly troubling about Abella J.'s decision is the extent to which her proposal resonates with the restrictive format for establishing an infringement of the equality rights guaranteed in the Charter set out in Law v. Canada. The current burden in human rights law (which is to establish a prima facie case of discrimination) ensures that the party who is designing and implementing workplace norms has the duty to ensure that these norms are as inclusive as possible in light of the norms' purpose and available resources. It is not clear why, as a matter of principle or policy, this burden is too high. For a discussion of the case see Judy Fudge \& John Kilcoyn, "McGill University Health Centre v. Syndicat des employés de L'Hôpital général de Montréal", The Court, February 12, 2007, online at: <http://www.thecourt.ca/2007/02/12/mcgilluniversity-health-centre-v-syndicat-des-employe-de-l'hopital-general-de-montreal/> and Kathryn Meehan, 
may not have selected health care workers for special, and very detrimental, treatment because the overwhelming majority of such workers were women, but nonetheless the impact of selecting health care workers was disproportionately to disadvantage women workers - a group which can be identified on the basis of a shared personal characteristic.

Despite her conclusion that the plaintiff's equality argument failed to meet the requirements of the first stage of the Law analysis, Garson J. went through the remaining two steps. She considered the second step: Is the claimant subject to differential treatment based on one or more enumerated and analogous grounds? Here she specifically considered the dicta in Dunmore and Delisle that occupational status could be an analogous ground, ${ }^{100}$ and asked whether health care workers were more like agricultural workers (as was the case in Dunmore) or police officers (as was the case in Delisle). She concluded "they cannot be described in the same way as the agricultural workers in Dunmore. I do not think for the purposes of a s. 15 analysis the occupational group 'health care workers' or 'unionized health care workers' can be seen as sharing the same immutable characteristics". ${ }^{101}$ According to her, the unique circumstances surrounding health care work is the distinguishing factor, and correspondence with sex or women's work is not the basis of the legislation. Thus, she concluded that the second step of the Law test had not been made out.

Once again the problem with Garson J.'s analysis is that she ignores the adverse impact that legislation targeting unionized health care workers has upon women workers, a group that has been historically discriminated against. ${ }^{102}$ It appears that she has imported the requirement that the government "intend" to target health care workers because they are women into her analysis of the second step in the Law framework. A tacit requirement of intentional discrimination is the only way to understand the following assertion:

The true effect of the law is not upon "women" or "those who perform women's work" it is upon those who perform health care work in British Columbia's unionized public sector. The unique circumstances

"McGill University Health Centre: Some Clarification on Discrimination and the Duty to Accommodate" (2008) 13 C.J.L.E.L. 419.

100 She also noted that in both cases it was L'Heureux-Dubé J. writing alone who addressed this question: B.C. Health Services, supra, note 86, at para. 178 (B.C.S.C.).

101 Id., at para. 180.

102 Id., at para. 162, the undisputed evidence of Pat Armstrong. 
surrounding that work is the distinguishing factor: correspondence with sex or "women's work" is not the basis of the legislation. ${ }^{103}$

Given that Garson J. accepted the evidence that the overwhelming majority of workers who would be affected by Bill 29 are women, it is indisputable that a "true effect" of the law is upon women workers. Moreover, it is not clear what she meant by the "unique circumstances surrounding that work", unless she is referring to the fact that the work was covered by a collective agreement that the government no longer wanted to honour.

In considering the third step, does the differential treatment discriminate, Garson J. focused on dignity. She concluded: "[w] hile the plaintiffs are clearly aggrieved by the legislation for various justifiable reasons, the impact upon them is not of the quality or characteristic that impacts their dignity in the sense that it engages s. $15 " .{ }^{104}$ She did not offer any argument in support of this conclusion; instead she simply recited a list of cases in which the Supreme Court and various appeal courts had decided that a distinction based on a personal characteristic did not impair the dignity of the individuals who shared the characteristic. ${ }^{105}$

The British Columbia Court of Appeal upheld each element of the trial judge's section 15 analysis. Moreover, speaking for a unanimous bench, Thackery J. went on to elaborate that the appellants' submission:

... was more of a political assault than a legal argument. Its emotional base does not contain any reference to evidence or to legal principles that ground an argument based upon the test in Law. There can be no doubt but that the appellants, whether they be the associations of individuals or the individuals themselves, are angry. They were given, by one government, rights that were used to improve union power and individual incomes. Another government took away some of that power and some of the economic benefits. ${ }^{106}$

Despite the fact that it was not necessary for the Supreme Court of Canada to address the section 15 claim, since the appellant unions were successful under section 2(d), the Court provided a cursory and

$103 \quad I d .$, at para. 181.

$104 I d$., at para. 189. It is not clear the extent to which $R . v$. Kapp, supra, note 72, will change this emphasis upon dignity. However, it is clear that the Court was concerned that dignity had become an additional element for a claimant to prove rather than a principle informing the Court's approach to equality.

$106 \quad$ Id., at para. 188. [2004] B.C.J. No. 1354, 243 D.L.R. (4th) 175, at paras. 136 and 137 (B.C.C.A). 
disappointing discussion of the equality argument. ${ }^{107}$ The Supreme Court signalled its refusal to consider seriously the equality claim when it refused LEAF's motion to intervene. ${ }^{108}$ The majority dismissed the appellant unions' section 15 claim in six paragraphs. Despite the pain inflicted by Bill 29 on health care workers, the Court refused to depart from the view of the trial court judge that the effects of the legislation did not constitute discrimination under section $15 .{ }^{109}$ The Court concluded:

... the distinctions made by the Act relate essentially to segregating different sectors of employment, in accordance with the long-standing practice in labour regulation of creating legislation specific to particular segments of the labour force, and do not amount to discrimination under s. 15 of the Charter. The differential and adverse effects of the legislation on some groups of workers relate essentially to the type of work they do, and not to the persons they are. Nor does the evidence disclose that the Act reflects the stereotypical application of group or personal characteristics. Without minimizing the importance of the distinctions made by the Act to the lives and work of affected health care employees, the differential treatment based on personal characteristics required to get a discrimination analysis off the ground is absent here. ${ }^{110}$

The Court's focus on combating stereotypes as the rationale for providing constitutional protection for equality rights enabled it to sever its analysis of the equality claim from its analysis of the freedom to

107 In Dunmore, supra, note 85, at para. 90 the majority of Court refused to address the s. 15 claim after the appellants were successful with the s. 2(d) argument.

108 Melina Buckley \& Fiona Sampson, "LEAF and the Supreme Court of Canada Appeal of Health Services and Support-Facilities Subsector Bargaining Assn. v. British Columbia" (2005) 17 C.J.W.L. 473.

109 Thousands of workers in the health services sector lost their jobs and accrued seniority, and suffered substantial wage cuts, ranging from 15 to 40 per cent: see Marjorie Griffin Cohen \& Marcy Cohen, A Return to Wage Discrimination: Pay Equity Losses through the Privatization (Canadian Centre for Policy Alternatives, Vancouver, B.C.: April 2004) online at: <http://policyalternatives.ca/documents/BC_Office_Pubs/bc_pay_equity.pdf $>$ [hereinafter "Griffin Cohen \& Cohen"]; David Canfield, "Neo-liberalism and Working-Class Resistance in British Columbia: The Hospital Employees' Union Struggle, 2002-2004” (2006) 57 Labour/Le Travail 941.

110 B.C. Health Services, [2007] S.C.J. No. 27, [2007] 2 S.C.R. 391, at para. 165 (S.C.C.). I am sympathetic to Brian Langille's claim in "Can We Rely on the ILO? (Don't Ask the Supreme Court of Canada)" (2008) C.L.E.L.J. 363, at 389-90 that s. 15 might provide an alternative (and, perhaps, more suitable) basis for addressing some claims relating to constitutional labour rights. However, my reading of the Supreme Court's current approach to equality rights indicates that his solution to the conundrum of s. 2(d) is extremely unlikely. Even under $R$. v. Kapp, supra, note 72, it is unlikely that the Supreme Court of Canada would consider the legislation to be discriminatory since the emphasis on stereotypes is a central element of the concept of discrimination at play in Andrews, [1989] S.C.J. No. 6, [1989] 1 S.C.R. 143 (S.C.C.). 
associate despite the fact that it had earlier justified the latter as including a right to bargain collectively because it promotes the Charter value of substantive economic equality. Moreover, the Court's analysis ignored the extent to which labour legislation reflects and reinforces historical patterns of labour market discrimination and segregation. ${ }^{111}$ The "long standing practice in labour regulation of creating legislation specific to particular segments in the labour force" may be neutral on its face but it has profoundly disparate and disadvantageous impacts upon workers. The historical exclusion of agricultural and domestic workers from private sector labour relations legislation is simply one contemporary example. ${ }^{112}$ The majority's assertion that "the differential and adverse effects" of the impugned legislation on some groups of workers "relate essentially to the type of work they do, and not to the type of persons they are" demonstrates a cavalier disregard of statements made earlier in the judgment that emphasize the significance of work to an individual's sense of identity, self-worth and dignity. ${ }^{113}$ And the claim that the "evidence does not disclose that the Act reflects the stereotypical application of group or personal characteristics" evinces a complete lack of awareness of the extent to which ascribed characteristics such as sex are used to channel individuals into given occupations. This lack of awareness is surprising given that Abella J. was part of the majority, and in 1984 she had released a report called Equality in Employment that documented the degree of occupational discrimination experienced by women. ${ }^{114}$ Most remarkably, the Court appears to have forgotten Binnie J.'s remark in Newfoundland $v$. NAPE, made only three years earlier,

111 Judy Fudge, "Rungs on the Labour Law Ladder: Using Gender to Challenge Hierarchy" (1997) 60(2) Sask. L. Rev. 237-63; Judy Fudge \& Leah Vosko, "Gender, Segmentation and the Standard Employment Relationship in Canadian Labour Law and Policy" (2001) 22 Economic and Industrial Democracy 271-310; Judy Fudge \& Eric Tucker, "Pluralism or Fragmentation?: The Twentieth Century Employment Law Regime in Canada" (2000) 46 Labour/Le Travail 251-306; Judy Fudge \& Eric Tucker, Labour Before the Law: The Regulation of Workers' Collective Action in Canada, 1900 to 1948 (Don Mills: Oxford University Press, 2001).

112 Judy Fudge, "Little Victories and Big Defeats: The Rise and Fall of Collective Bargaining Rights for Domestic Workers in Ontario" in Abigail Bakan \& Daiva Stasiulis, eds., Making the Match: Domestic Placement Agencies and the Racialization of Women's Household Work (Toronto: University of Toronto Press, 1997), at 119-45; Judy Fudge, Affidavit: Between Michael Fraser on his own behalf and on behalf of the United Food and Commercial Workers Union Canada, Xin Yuan Liu, Julia McGorman and Billie-Jo Church v. Attorney General of Ontario. Ontario Superior Court of Justice, February 2004.

113 B.C. Health Services, supra, note 110, at para. 165.

114 Report of the Royal Commission on Equality in Employment (Abella Report) (Ottawa: Queen's Printer, 1984). 
that "[ $t]$ he value placed on a person's work is more than just a matter of dollars and cents". ${ }^{115}$

It would be unfair to fault Garson $\mathrm{J}$. for failing to refer to Newfoundland v. NAPE in 2003, since the Supreme Court of Canada released its judgment in 2004, a year after her decision. Newfoundland $v$. NAPE should have strengthened the B.C. health care unions' equality argument before the Supreme Court. As we saw, Binnie J. had no difficulty in concluding that the Newfoundland and Labrador wage control legislation violated the health care workers' equality rights. Although the B.C. legislation did not directly discriminate by specifically targeting women's work, as did the Newfoundland wagecontrol legislation, the impact of the B.C. legislation was indirectly to disadvantage a group of workers the overwhelming majority of whom were women. The fact that the Supreme Court did not refer to the 2004 case in its equality analysis of the B.C. Health Services case, especially given that the majority referred to the earlier case in its analysis of whether the infringement of the freedom to associate by the B.C. legislation was justified, is inexplicable. ${ }^{116}$ Moreover, given the pay equity subtext of the B.C. Health Services case, which I shall explain, the failure of the Supreme Court to address seriously the equality argument is inexcusable. ${ }^{117}$

In British Columbia there is no pay equity legislation that imposes an obligation on either public or private sector employers to remedy the widely recognized wage gap between female dominated and male dominated jobs. Unions, such as the Hospital Employees Union, which represents 90 per cent of health care workers in British Columbia, embarked on an aggressive strategy of closing what was recognized to be a gender-based wage gap between jobs filled predominantly by women and jobs filled predominantly by men. This strategy involved human rights complaints, negotiations backed by strikes and grievances. In 1995 the British Columbia government, which was led by the New Democratic Party, introduced the Public Sector Employers' Council Pay

115 Newfoundland v. NAPE, [2004] S.C.J. No. 61, [2004] 3 S.C.R. 381, at para. 40 (S.C.C.). He quoted the now notorious dissent of Dickson C.J.C. in the Alberta Reference, [1987] S.C.J. No. 10, [1987] 1 S.C.R. 313, at 368 (S.C.C.), that "[w]ork is one of the most fundamental aspects in a person's life." The Supreme Court's equality analysis in Newfoundland v. NAPE was brought to the Court's attention by the appellants in their factum, the Health Services and Support-Facilities Subsector Bargaining Assn. v. B.C., Court File No. 30554, at paras. 137, 165.

116 B.C. Health Services, supra, note 110, at paras. 145 and 147.

117 The pay equity context of the case was brought to the Court's attention by the appellants in their factum, supra, note 115, at para. 127. 
Equity Framework, which imposed an obligation on public sector employers such as hospitals to develop pay equity plans, to file these plans with the government, and to put aside 1 per cent of pay roll each year in order to close the gender-based wage gap. The same year, the Fraser Institute released a report claiming that the high wages for nonclinical health care workers was causing a crisis in the Canadian health care system. By 2001, health care workers in British Columbia enjoyed the highest wage rates and the lowest wage gap between men and women of any jurisdiction in Canada. ${ }^{118}$

When the Liberal Party was elected to form the British Columbia government in 2001, pay equity adjustments for the public sector were scheduled for 2002 and 2003. Instead of revoking the Public Sector Employers' Council Pay Equity Framework, the government repealed the amendment to the Human Rights Act, which had been enacted by the N.D.P. government in its dying days, that imposed pay equity obligations on private sector employers. ${ }^{119}$ At the same time, it appointed a Task Force, led by a single commissioner (who later represented the government in its defence of the Charter challenge brought by health care unions against Bill 29) to recommend whether or not pay equity legislation for the private sector was required. In her report, Nitya Iyer recommended against introducing pay equity legislation for the private sector, although she acknowledged the existence of a gender-based wage gap, part of which could only be explained by the history of discrimination against women in employment. ${ }^{120}$ Thus, one effect of Bill 29, which resulted in the privatization of many non-clinical health care worker jobs, was not only to relieve the government of having to pay higher wages to health care workers in female-dominated jobs, but to permit the private firms that were contracted to provide services to revert to paying discriminatory wages with little risk that their practices would be challenged. ${ }^{121}$

118 Marjorie Griffin Cohen \& Marcy Cohen, "Privatization: A Strategy for Eliminating Pay Equity in Health Care" in Kate Bezanson \& Meg Luxton, eds., Social Reproduction: Feminist Political Economy Challenges Neoliberalism (Kingston and Montreal: McGill Queens Press, 2006); Griffin Cohen \& Cohen, supra, note 109.

119 Id.

120 Nitya Iyer, Working Through the Wage Gap: Report of the Task Force on Pay Equity (Victoria: February 28, 2002).

121 Griffin Cohen \& Cohen, supra, notes 109 and 118. 


\section{PutTing CHARTER Rights to Work: THE REALPOLITIK OF LITIGATION}

The Supreme Court of Canada's conception of the Charter's guarantee of the freedom to associate and equality is both shaped and reinforced by the practicalities of constitutional litigation. It takes a great deal of time and resources to mount a constitutional challenge. When unions challenge legislation on the ground that it interferes either with the freedom to associate or equality rights they are challenging legislation that has already taken effect. Thus, even when they are successful, as they were in Dunmore and the B.C. Health Services case, the Supreme Court's remedy is typically to suspend the declaration of invalidity in order to give the government time to come up with a solution. In Dunmore, the Ontario government adopted a parsimonious approach to the Supreme Court's ruling, one that did not even provide for collective bargaining rights for agricultural workers. ${ }^{122}$ Moreover, the subsequent Liberal government, which in its election platform promised to provide collective bargaining rights to agricultural workers, vigorously defended against a constitutional challenge to the former Conservative government's Agricultural Employees Protection Act. ${ }^{123}$ After the Supreme Court of Canada's decision in the B.C. Health Services case the parties were able to agree upon a substantial settlement to the case, $\$ 85$ million, the vast majority of which will be distributed to individual workers. ${ }^{124}$ However, the unions which brought the successful challenge still had to go through the laborious and expensive process of organizing the workers' whose jobs were contracted out because the changes to the successor rights provisions in Bill 29 did not infringe s. 2(d) of the Charter. Nor will the successful challenge to Bill 29 prevent the B.C. government from either continuing to privatize health care services or from changing collective agreements as long as the government consults with the unions representing the workers before doing so.

Constitutional litigation does not take place on a level playing field; governments that are defending impugned legislation typically have a

122 Agricultural Employees Protection Act, 2002, S.O. 2002, c. 16.

123 Fudge, affidavit, supra, note 112.

124 Vaughn Palmer, "Liberals, health unions reach agreement at point of judicial gun" Vancouver Sun, January 28, 2008, at A3. The government has also enacted legislation to repeal the offending provisions of Bill 29: see Bill 26 - Health Services Amendment Act, 2008, 4th Sess., 38th Parl., 3rd Reading, May 29, 2008. 
great deal more resources than do the unions that are challenging the legislation. This gives the government a big advantage, and puts unions on the defensive. ${ }^{125}$ Moreover, the huge amount of resources spent on lawyers and experts that goes into defending and challenging legislation would be much more usefully spent on developing policies that respond to the profound changes in the labour market that have occurred over the past 20 years. Once the parties begin to spend resources on either challenging or defending a specific piece of legislation they dig into their positions and lose the ability to think of creative solutions to the conflict within which they are engaged.

Constitutional litigation tends to promote a winner-take-all approach that influences how the parties approach both the evidence they adduce and the arguments that they make. My own very limited experience as an expert witness in constitutional cases suggests that the parties are now much more concerned about the record than they were in the past. ${ }^{126}$ However, the fact that the record is of increasing significance in labour cases does not necessarily mean that the quality of the evidence has improved. In many cases, it simply means that the behaviour of the lawyers involved has changed. An anecdote will illustrate this point. When I was cross-examined on the affidavits that I prepared for Dunmore, the cross-examination was very similar to a thesis examination - courteous, rigorous and directed to the matters at issue. Eight years later when I was cross-examined for the affidavits that I prepared for Fraser v. Ontario, the cross-examination was an ordeal of endurance marked by discourtesy. ${ }^{127}$

Constitutional litigation is not compatible with the complexity of historical nuance or sticky policy issues that inevitably involves tradeoffs. ${ }^{128}$ Lawyers have an incentive to simplify the issues at stake in Charter cases and they necessarily engage in results-based reasoning since they are working for clients who give them instructions and who

125 According to Paul Cavalluzzo, unions which bring Charter challenges to legislation must be prepared to spend half a million dollars to take a case to the Supreme Court of Canada (remarks made by him at the Constitutional Case 2007, Conference, Toronto, April 18, 2008).

126 See Dunmore, [2001] S.C.J. No. 87, [2001] 3 S.C.R. 1016, at para. 35 (S.C.C.) for the significance of the record in the determination of the violation of s. 2(d) and B.C. Health Services, supra, note 110, at para. 156 regarding the significance of the record for the s. 1 analysis.

127 For example, despite having been accepted as an expert on matters pertaining to agricultural workers and the labour law relating to them, in Fraser my curriculum vitae was subject to several hours of extensive and aggressive cross-examination.

128 Eric Tucker, "The Constitutional Right to Bargain Collectively: The Ironies of Labour History in the Supreme Court of Canada” (2008) 61 Labour/Le Travail 151. 
want to win. The parties often over-egg their arguments and positions since constitutional litigation, not infrequently, is as much about political symbolism as it is about legal argument. For these reasons, constitutional litigation tends to reinforce rather than act as an antidote to partisan politics.

The most profound problem that I see with constitutional litigation in pursuit of protecting labour rights is that even when it is successful it typically is defensive. Unions have gone to court to defend the key features of industrial pluralism - a system of collective bargaining that originated with the Wagner Act in 1935 and that was adapted to Canada with the Wartime Labour Relations Regulations ${ }^{129}$ in 1944. That system was designed for the post-war economy, and even at its apogee covered less than half of the working population in Canada. Since the early 1980 s, at the very time the Charter was entrenched, this system has proven to be less effective as the supply and demand sides of the labour market have changed; the wages of unionized workers have stagnated and union density has declined. ${ }^{130}$ While it is heartening for people who are concerned with the dignity of workers that the Supreme Court has elevated collective bargaining to a constitutional right, it is unlikely that defensive battles fought in courts can turn the economic and political tide that has undermined the basis for transforming these rights into job security and improved wages for working people. Nor is it likely the courts will devise models of representation that can revive a flagging labour market. Courts appear to be helpful only when unions are weak.

\section{CONCLUSION}

Giving content to fundamental rights is not an easy task. Moreover, in a democracy it is appropriate that courts exercise humility when using their mandate to strike down legislation. In the two cases in which the Supreme Court of Canada has begun to elaborate a more robust constitutionally protected freedom to associate in the labour context, the governments whose actions were successfully challenged had introduced legislation repealing collective bargaining rights without consulting with the trade unions who represented the affected workers and they had used

\footnotetext{
129 Order-in-Council P.C. 1003.

130 Judy Fudge, "Beyond Vulnerable Workers? Towards a New Standard Employment Relationship" (2005) 12(2) C.L.E.L.J. 145-70; Judy Fudge, "The New Workplace: Surveying the Landscape", Pitblado Conference, Winnipeg, November 9 and 10, 2007.
} 
their majorities to pass legislation without a public debate. After the B.C. Health Services case, at a minimum, governments will have to consider public sector workers' rights and to consult with their unions before introducing draconian legislation that substantially interferes with the process of collective bargaining. Thus, the Court's emphasis on the government's duty to bargain in good faith fosters democratic deliberation and imposes an inhibition on an instinctive vilification of public sector workers' rights.

Despite its newfound appreciation of workers' rights, the Supreme Court of Canada has endorsed only a thin, procedural understanding of collective bargaining that tends to reify the existing industrial pluralist model of labour legislation. Nor has it grappled with the hard question of when the state has an obligation to protect workers from the exercise of private power - a power that is shaped and reinforced by deeply embedded common law rules. ${ }^{131}$ Although the Court invoked substantive equality as one of the Charter values that supported providing constitutional protection for the right to bargain collectively, it did not develop the link between equality and the freedom to associate. ${ }^{132}$ In fact, the Court's dismissive treatment of the health care workers' equality claim suggests that substantive equality has little judicial purchase in the world of work.

131 In Dunmore, supra, note 126, the Court narrowly circumscribed the positive obligation on the state to provide legislative protection for labour rights and in B.C. Health Services, supra, note 110 , the Court did not question this limited obligation.

132 According to Sheldon Leader, Freedom of Association: A Study in Labor Law and Political Theory (New Haven: Yale University Press, 1992), at 270-71, equality is the normative grounding for the freedom to associate: "freedom to associate does not simply fit into the scheme of equal liberty, whereby one aims to find an appropriate equilibrium between rival claims to space for free action. Instead, there is built into the very specification of that space, describing the type of liberty which the right is aiming to protect, a demand for equality." 
